\title{
Implementation of school based management in improfing the quality of teachers
}

\author{
Almy Soleh Wahyu ${ }^{1}$, Happy Fitria ${ }^{2}$, Yessi Fitriani ${ }^{3}$ \\ ${ }^{1}$ SMA Negeri 1 OKU \\ ${ }^{2}$ Universitas PGRI Palembang
}

\begin{tabular}{l} 
Article Info \\
\hline Article history: \\
Received Jul $12^{\text {th }}, 2021$ \\
Revised Aug $16^{\text {th }}, 2021$ \\
Accepted Aug $30^{\text {th }}, 2021$ \\
\hline
\end{tabular}

\section{Keyword:}

School based management Principal and teacher quality

\begin{abstract}
The purpose of this study was to describe the implementation of school based management in proving the quality of teachers In State Senior High School No.4 OKU. This research uses qualitative methods with a descriptive approach. The informants as sources in this study were the principal. Deputy principal, teachers, administrative staff and guardian of students. In collecting the data the researcher used were observation, interview and documentation techniques. Based on the research result it can be concluded that First, the principal in State Senior High School No.4 OKU is capable of implementing school based management well. Second, there is an increase in teacher quality as seen from teacher completence. Third, school principals is able to improve teacher quality through planned and gradual programs. Fourth, the principal is able to improve the quality of the school.
\end{abstract}

C 2021 The Authors. Published by IICET.

This is an open access article under the CC BY-NC-SA license

(https://creativecommons.org/licenses/by-nc-sa/4.0

\section{Corresponding Author:}

Almy Soleh Wahyu

SMA Negeri 1 OKU

Email: almywahyu2@gmail.com

\section{Introduction}

So that it takes place effectively and efficiently. In all educational practices, the curriculum has a fairly central role, determining the method of implementation and the consequences of schooling. The curriculum plays an important role in education and the growth of human life, It is not necessary to carelessly plan the program. To achieve educational objectives, curriculum creation must have a solid base. The program often requires educators in its execution [1]. Therefore, in understanding this, the teacher is the primary position, namely the teacher who teaches, educates and prepares students to live in the age to come.

Schools as formal principal-led educational institutions and the inclusion of students with various characteristics require a range of educational facilities with distinct environmental conditions. One of the variables that decide a school's performance is whether the leadership is effective or not. [2] that the failure and success of an organization is primarily decided by the leader because the leader is the controller and determinant of the path that the organization needs to take towards the goals to be achieved. This can be achieved if the principal has the power to control the school in compliance with the requirements of the community and the needs of his students. The leadership of the principal is one of the deciding factors that can mobilize all school resources through organized and incremental programs to be able to realize the school's vision, mission, priorities and goals [2]. However, in order to preserve quality and monitor the process of 
improving quality, In order to act as an indicator to measure the progress of quality management, there must be a national defined and approved standard.

School Based Management is a new paradigm of education, according to [2], which offers broad autonomy at school level (community involvement) within the context of national education policies. The aim of introducing School Based Management is to improve the standard of education through independence and school initiative by growing the awareness of school residents and the community in providing education in schools by managing and motivating the resources available. It will increase the sense of responsibility of parents, society and government about the quality or quality of school education, with the concern of school residents and the community.

In teaching and learning operations in classrooms, teachers have a very important role. [2] stated, the teacher is an important factor that has a major influence and even greatly determines the learning success or failure of learners. Therefore, in generating highly performing pupils, competent teachers are required. [3], professional teachers can be seen in the performance of all their services from their responsibilities as teachers. Low teacher efficiency is one of the reasons of low quality education. Internal or external variables may influence the causes of low teacher efficiency. Job discipline is an internal factor that may influence the process of increasing or decreasing the quality of teachers. Neglected discipline of work can become a bad practice to minimize efficiency in the execution of the educational method [4].

There are two reasons why it is necessary for school-based management to be introduced in the Indonesian education management and delivery system: (1) School-based leadership will improve the responsibility of school principals and teachers to students, student parents, and the community; (2) transparency to all stakeholders to provide advice and feedback to recognize critical school policies needed by schools [5].

There are many challenges, both internal and external, to the method of introducing school-based management based on field studies. As for the internal challenges, namely schools with a shortage of human resources that lead to the introduction of school-based management, school facilities and infrastructure are insufficient, there are school representatives who do not obey a lack of discipline in complying with school regulations and restricted budgets. Although there are external restrictions, there are parents / guardians. of students who do not respect the standard of education.

It can be seen that the quality of teachers there has improved very well, based on the results of observations made at SMA Negeri 4 Ogan Komering Ulu (OKU), as seen by many teachers who continue their studies to the bachelor level and teachers whose last education was in strata 2, Some are appointed as civil servants and there are educators appointed in the OKU district as school principals and deputy principals. This suggests that the standard of the teachers has improved as well. There is an issue with seeing the principal in the management of human resources to further improve their efficiency there.

"Implementation of School Based Management in Efforts to Improve the Quality of Education at MIN Hadiluwih, Sragen Regency"Implementing School Based Management at MIN Hadiluwih, Sragen Regency in Efforts to Improve the Quality of Education. Based on the research findings, it is said that the introduction of MIN Hadiluwih Sumberlawang's School Based Management has proven to have an impact on improving the standard of education. The parallels between previous study and research carried out by scientists are all school-based management studies, Although the difference between previous research and research carried out by researchers is that researchers do not investigate the quality of education, but researchers want to examine how school-based management in OKU 4 SMA Negeri can promote enhancement of teacher quality.

The researcher wants to conduct a study entitled Implementation of School-Based Management in Improving the Quality of Teachers of SMA Negeri 4 OKU on the basis of the definition above. In this analysis, the formula for the problem (1) How is the State Senior High School No.4 OKU implementation of school-based management, (2) What is the effort of the principal to boost the standard of teachers at State Senior High School No.4 OKU. The aims of this analysis are: (1) To find out how to improve the quality of teachers at State Senior High School No.4 OKU by introducing school-based management, (2) Finding out about the principal's attempts to boost the standard of teachers at State Senior High School No.4 OKU

\section{Method}

This thesis involves field research, namely research that exposes facts in the field using literature data with observations and interviews. With descriptive approaches, this review uses qualitative analysis. [6], the descriptive approach is to find the best interpretation of evidence. State Senior High School No.4 OKU, located at Jalan Kolonel H. Wahab Sarobu, RT.03/RW.01, Sukaraya, East Baturaja District, Ogan Komering Ulu Regency, South Sumatra 32112, conducted this study. 
The thesis was carried out for four months by changing the schedule of the researchers from August to November 2020.The technique of observation is an activity of specifically observing the object of study in order to understand the activities carried out [7]. Researchers would use passive participatory observation in this study where the researcher is present, but only observes, in implementing school-based management. Where insights are seen from the principal's role in the management of the school, teacher skills, facilities and equipment, interactions between members of the school, learning events, and also the design of the study location to be examined.

The interview is a technique of data collection that operates directly from the source to find out information. The opinion [8] is that the interview is a question and answer that occurs between people seeking information (interviewers) and people providing information (informants) in order to gather or acquire data. Factors that can affect the flow of information in the interview are interviewers and respondents. [7] The interviewer is an officer who gathers information in order to be able to clearly express questions and to allow respondents to address all questions and correctly record all required information. Respondents, meanwhile, are data suppliers who are supposed to be able to answer all questions explicitly and entirely.

It is hoped that researchers would obtain more in-depth information by conducting interviews in the form of informants' explanations relevant to the introduction of school-based management In State Senior High School No.4 OKU. In order for the interview to be concentrated and transparent so that it is easier for the interviewer to collect specific details, it is first prepared in compliance with the required data mining before the question for the interview, the questions that have been prepared will vary according to the needs and requirements of the interview. The researcher therefore interviewed persons in this sample who were specifically involved with what was the subject of the study, namely the application of school-based leadership in enhancing the quality of teachers In State Senior High School No.4 OKU. So, researchers get reliable and planned results.

Documentation, which means printed objects, derives from the word document. The researcher examines written items such as books, journals, records, laws, minutes, sessions, regular notes and so on in the application of the reporting process. The documentation in this analysis is used to collect data on the implementation of school-based management to supplement data on teachers who have increased the consistency of current documentation or archives [9].

Researchers need this approach to review school archives. Among other items, this tool is used to collect data on records of events that have existed in the past, as well as school activities programs for teacher administration reports, such as lesson plans that, when retrieved by this method, are more accurate and efficient.

\section{Results and Discussions}

\section{The Description of Data for Analysis}

The test results were collected by performing a survey-related interview process with school parties, as well as by conducting a documentation study performed by the researchers from July to December 2020. To carry out the analysis to find out about 1) How to incorporate school-based leadership In State Senior High School No.4 OKU; 2) Attempts of the principal to boost teacher efficiency In State Senior High School No.4 OKU; 3) Enabling factors in the introduction In State Senior High School No.4 OKU school-based management; 4) Inhibiting variables in In State Senior High School No.4 OKU 's introduction of school-based management.

\section{The State Senior High School No.4 OKU Method for Introducing School Based Management}

The method is a sequence of structured steps that are interrelated with each other concerning the execution or activities, jointly helping each other to process inputs to generate the desired output or output. Implementation is the implementation of what has been planned before. The intention of scheduling would fail without execution. If the execution is carried out, then the planning priorities have been successfully executed.

The implementation method is a set of manually arranged implementation sequences. The implementation method overview begins with the presence of data (input), process (process), output/output (output).

Centered on the findings of interviews with the principal of State Senior High School No.4 OKU conducted by researchers. Ibu Hj. Jumiati, S.Pd., M.M. On September 18, 2020, she said: "Starting at the feedback level, where the principal collects input from multiple groups, both teachers and workers and the society, the process of introducing school-based management at SMA Negeri 4 OKU is going well. This inputs and suggestions are collected every semester by having meetings with the student guardians. To get public 
criticism and recommendations, though, use an indirect approach by paying attention to the community's needs. In addition, input is then selected to be processed in the form of ideas, the school implements the idea in the school environment at the stage of the process, still involving the community to participate, for instance, the community wants to help prepare for the competition. Then the success of the school in different fields, such as choirs, dance contests, basketball, badminton, and scouts, achieved numerous advances and achievements. The OKU district championship has achieved this achievement, and it is expected to follow it to the district level in the future."

It can be inferred, based on the results obtained by the researchers, that the process of introducing schoolbased management at SMA Negeri 4 OKU has been going well. This can be seen from the results that researchers first get at the input point, the principal often holds meetings with his subordinates, then each semester conducts deliberations with student guardians and welcomes all constructive feedback, suggestions, and school input. Second, the school principal implements feedback and input from its members and the community, namely the process stage, this implementation can not be isolated from the school principal's oversight, and also from the community's involvement since the community has contributed in the form of energy and resources. Third, namely the production level, the results obtained are to improve the harmony of the relationship of the school with the community, then the students achieve achievements in different fields in order to increase the standard of education at SMA Negeri 4 OKU.

\section{The Principal's Efforts to Improve Teacher Quality in State Senior High School No.4 OKU}

Effort is an act of effort by a person to do what he wants. For example, a school principal who wants to improve the quality of teachers where he works, the principal must try to do things that can improve the quality of teachers in schools.

In this case the principal plays an important role in being able to improve the quality of teachers in the schools he manages, with various efforts made by the principal so that the school provides the best service to education consumers, namely the community and students. One of these efforts is the implementation of school-based management because in essence the government's goal of proclaiming SBM in every school is to improve the quality of education which can have an effect on improving the quality of teachers, therefore school principals must strive to improve SBM implementation in their schools.

Efforts to improve teacher quality are something that is usually done by school principals and every school principal must have its own efforts in improving the quality of teachers in their schools. Should be Mrs. Hj. Jumiati, S.Pd., M.M. as the principal in State Senior High School No.4 OKU also has an effort to improve the quality of teachers in this school, through interviews the researchers conducted, he revealed:"The programs carried out by the principal in improving the quality of teachers, namely teachers are included in trainings on technology science and English. Even the principal has held workshops and the qualifications of teacher educators have been motivated to improve, seen from several teachers who take bachelor degrees in PGRI Palembang University in the Master of Indonesian Language Education study program and the Master of Education Management study program."

In line with the results of the interview with the State Senior High School No.4 OKU teacher Mr. Awan Purnomo, S.Pd. say that:"The implementation of school-based management in State Senior High School No.4 OKU has been going well by applying the basics of management science, namely Planning, Organizing, Actuacting, and Controling. In an effort to improve the ability to operate computers and the internet for the subjects they are taught, teachers in State Senior High School No.4 OKU have kept up with the times, 85 percent of teachers have used laptops in the learning process. Then in this pandemic atmosphere, teachers who have used laptops and the google classroom learning application in the learning process have increased to 100 percent . For separate learning, there are most teachers who use applications made by the ministry and there are also teachers who have made their own applications. Technology Science is the basis for assessing the learning process at in State Senior High School No.4 OKU. There are now 15 classes using a transmitter that is connected to a server in the room of the vice principal, so that students can test in the classroom and the scores can be analyzed in that location by the machine."

In addition, the principal's efforts to allow teachers to operate computers and the internet, in particular by providing teachers with instruction and training on how to operate computers and the internet. Then the principal's efforts to increase teachers' ability to suit their fields, namely the provision of facilities and infrastructure that can support the teaching skills of teachers. Based on the results of the interview, it can be concluded that the principal is good at providing policies that can help through school-based management to improve the quality of teachers in State Senior High School No.4 OKU. 
School Based Management (SBM) is the power and authority given to schools to manage school resources so that the process of teaching and learning can run effectively, which can affect the quality of school education. This is aimed at improving the quality of principals, teachers, employees and students in the school. [11] have explained, SBM is the management of resources carried out independently by schools, involving school-related interest groups in making decisions to improve the quality of schools. This implies that schools with all interest groups consisting of school principals, deputy principals, teachers and administrative staff as well as the community are conducting resource management to improve school quality.

Input (input), process and output are provided in the process of implementing school-based management obtained in the field (output). As explained [10], MBS features include elements of effective education that are categorized into: 1) Educational input, namely everything that needs to be accessible because a process requires it to take place. 2) Process, which is to change "something" to "something else" This involves four aspects, namely the decision-making process, the institutional management process, the management process of the program, and the process of teaching and learning. 3)Educational output, that is, school performance resulting from the process of learning and management.

State Senior High School No.4 OKU performed the School-Based Management process well, based on the researcher's analysis of the supporting theory above. This can be seen from the findings obtained by field researchers through interview techniques, observation and documentation that the implementation of State Senior High School No.4 OKU school-based management is: (1) Input, the principal conducts deliberations at this stage to make plans for all activities in both learning and extracurricular activities. Planning procurement, namely making a vision, mission and objectives, and making semester and annual programs through participatory decision-making meetings involving teachers, staff, student guardians and the community.The facts obtained by the researchers are in accordance with the view of .[10] The aim of School Based Management is to empower schools to encourage schools to make participatory decisions by granting authority (autonomy) to schools. The vision and mission of education must be adapted to local conditions and involve the community in order to achieve the objectives of SBM, to create a vision, mission and educational program and program so that the school can adapt to the needs of the community with the vision in State Senior High School No.4 OKU. (2) Process, the principal takes a policy at this stage on ideas, criticisms and suggestions from school stakeholders that are the best to be implemented in schools. In its implementation, the principal will then handle and supervise the running program. State Senior High School No.4 OKU has implemented SBM well on the basis of the investigator's analysis. This can be seen from the principal who implemented participatory historical decision-making policies by involving all interest groups, including teachers, staff employees, student guardians, and the community. (3) Output, this school has been able to initiate the community in the planning process and create a vision and mission as well as goals according to community needs, based on the SBM implementation process starting from the input, process and output carried out in State Senior High School No.4 OKU above. The principal managed and supervised the program, which is scheduled and regularly organized.

The outcome of this process is that the school produces output consisting of academic and non-academic achievements produced by the learning process and school management in the form of school accomplishments. So it can be concluded that in the process of implementing School Based Management, State Senior High School No.4 OKU succeeded. The principal managed and supervised theprogram, which is scheduled and regularly organized.

It can be concluded from the results of the interview with the principal of State Senior High School No.4 OKU that the principal is doing a lot of things that can support the improvement of teacher professionalism by implementing school-based management that is already good, although there are still various obstacles as an assessment value for the implementation of school-based management.

This is corrected by issuing different policies that can, in accordance with the desired planning, support the successful implementation of school-based management. Then, it can be seen from the results of the documentation data that State Senior High School No.4 OKU has properly implemented school-based management with an increase in teacher capacity that can be seen in the large amount of certified teacher data. 


\section{Conclusions}

School-based management implementation has a process that begins with feedback, namely the stage where the principal makes a program execution plan through deliberation involving all stakeholder groups, namely the deputy principal, teachers, administrative staff, student parents and the community. After program planning is implemented, including improving teacher competence, increasing the ability of teachers to operate computers and the internet. The principal then organizes the division of duties and responsibilities to interest groups according to their respective fields after scheduling the program. The implementation of what has been planned before is carried out at this stage of the two phases of the process, and this implementation can not be separated from the supervision of the principal so that the process runs well and smoothly and there is an evaluation. The principal also includes the community at this stage as a school resource. In addition, the third stage is the output or results of the implementation in State Senior High School No.4 OKU of school-based management, which is to produce students who excel and improve the quality of teachers.

\section{References}

Nasution, S. In 2012. Teaching and Curriculum. Jakarta: Earth Alphabetisation.

Mulyasa, E. In 2017. School-based administration: concept, strategy and execution. PT Remaja Rosdakarya: Bandung.

Fitria, et al. 2019. Efforts through Classroom Action Research Training to improve teacher competence. Newspaper. Volume 4, 15 Volume 4, 15

Arifin and Barnawi. In 2012. Instruments for Professional Teacher Performance Improvement and Assessment. Yogyakarta: Media Ar-Ruzz.

Suparlan. 2015. Theory-to-Practice school-based management. Jakarta: Earth Alphabetisation.

Tarjo. In 2019. Methods of Research 3X Read System. Yogyakarta: Publisher of Dee.

Riduwan. IN 2015. Teachers' Easy Learning Research - Employees and Youth Researchers. Alfabeta: Bandung.

Joko's Untoro. 2010. 10. Complete Material Summary and Complete Formulas Collection from Smart Book Lessons. Jakarta: Wahu Media's PT.

Suharsimi's Arikunto. In 2012. Managing Research. Jakarta: Earth Alphabetisation.

Widyastuti and others, 2020. Concepts, strategy and planning of school-based management. Medan: Foundation of Our

Mustingsih and Subarkah. In 2013. School Based Management Development Guidelines in Elementary Schools. Jakarta: Education and Culture Ministry. 